\title{
Pengembangan Pertanian Organik di Kelompok Tani Madya, Desa Kebonagung, Kabupaten Bantul, Daerah Istimewa Yogyakarta
}

\section{The Development of Organic Farming in Tani Madya Groups of Kebonagung Village, District Bantul, Daerah Istimewa Yogyakarta}

\author{
Firda Emiria ${ }^{1}$, Heru Purwandari ${ }^{1}$ \\ ${ }^{1}$ Departemen Sains Komunikasi dan Pengembangan Masyarakat, \\ Fakultas Ekologi Manusia, Institut Pertanian Bogor, Bogor
}

\begin{abstract}
Organic farming is agricultural activities that seek the use of outside intake and avoid the use of pesticides and synthetic fertilizer: The results showed that the organic farmers and conventional farmers have the high responses of organic farming. However, the characteristics of organic farmer have no relation with farmer's respons of organic farming. Then, in conventional farmers, formal education and the courage to take the risks have relation with farmer's respons of organic farming. This research also showed there are no relation between farmer's respons of organic farming with farmer's income. Nevertheless, can be predicted that there are chances of the conventional farmers to adopt the organic farming.
\end{abstract}

Keywords: organic farming, respons, income, conventional farmer

Abstrak

Pertanian organik adalah kegiatan pertanian yang berusaha penggunaan asupan luar dan menghindari penggunaan pestisida dan pupuk sintetis. Hasil penelitian menunjukkan bahwa petani organik dan petani konvensional memiliki respon yang tinggi dari pertanian organik. Namun, karakteristik petani organik tidak memiliki hubungan dengan petani respon pertanian organik. Kemudian, di petani konvensional, pendidikan formal dan keberanian untuk mengambil risiko memiliki hubungan dengan respon petani dari pertanian organik. Penelitian ini juga menunjukkan tidak ada hubungan antara respon petani dari pertanian organik dengan pendapatan petani. Namun demikian, dapat diprediksi bahwa ada kemungkinan petani konvensional untuk mengadopsi pertanian organik.

Kata kunci: pertanian organik, respon, pendapatan, petani konvensional organik

\section{Pendahuluan}

Indonesia merupakan negara agraris yang identik dengan pertanian. Potensi di bidang pertanian yang dimiliki Indonesia dapat dikembangkan dan dapat menjadi salah satu bidang yang sangat penting perannya dalam meningkatkan pendapatan nasional. Berdasarkan data Badan Pusat Statistik (BPS), pada Bulan Februari 2013 dapat diketahui bahwa sebesar 39.959.073 penduduk Indonesia mengandalkan sektor pertanian sebagai lapangan pekerjaan utama. Angka tersebut mengalami kenaikan sebesar 2,77\% dari perhitungan sebelumnya pada Bulan Agustus 2012. Kondisi tersebut menunjukkan bahwa bidang pertanian memiliki daya tarik tersendiri untuk dijadikan lapangan pekerjaan utama, salah satunya yaitu bidang pertanian yang merupakan sumber makanan utama masyarakat.

Selama ini, sebagian besar pertanian yang dikembangkan di Indonesia adalah pertanian modern yang dicirikan dengan sistem usahatani yang menggunakan bahan-bahan kimia yang berbahaya bagi kesehatan dan lingkungan. Namun, seiring dengan berjalannya waktu banyak pakar lingkungan menyadari bahwa penggunaan bahan kimia tersebut dapat menimbulkan dampak negatif berupa penurunan produktivitas tanah akibat penggunaan pupuk kimia serta rusaknya keseimbangan ekosistem akibat penggunaan pestisida. Keadaan tersebut akhirnya mendorong individu dan kelompok organisasi menyuarakan gerakan untuk mempraktikkan usahatani alami yang ramah lingkungan dengan berbagai istilah seperti "organik" atau "alternatif" dan selanjutnya berkembang menjadi pertanian organik seperti saat ini.

Indonesia merupakan negara ketiga di Asia dalam pengembangan pertanian organik 
setelah China dan India (Winarno dalam Siahaan, 2009). Berdasarkan data Statistik Pertanian Organik Indonesia (SPOI) yang diterbitkan oleh Aliansi Organis Indonesia (AOI), sampai tahun 2011 tercatat bahwa luas area pertanian Indonesia tahun 2011 adalah 225.062,65 ha dengan status $90.135,5$ ha merupakan area tersertifikasi pertanian organik, 3.8 area dalam proses sertifikasi pertanian organik dan 134.917,66 ha merupakan area tanpa sertifikasi organik (Ariesusanty et al., 2012). Sangat disayangkan, jika dibandingkan tahun lalu, luas lahan ini mengalami penurunan sebesar 5,77\%, terutama karena menurunnya luas area pertanian organik tersertifikasi.

Berkurangnya luas area pertanian organik menunjukkan bahwa jumlah petani dan luas lahan organik di Indonesia masih rendah. Hal ini dapat dilihat dari data hasil survey lapangan penulis pada bulan Januari hingga Maret 2013 yang menunjukkan bahwa jumlah petani organik murni di Kabupaten Bogor masih sangat sedikit dibandingkan petani konvensional. Keadaan ini menunjukkan kondisi yang bertolak belakang dengan tingginya permintaan konsumen atas pertanian organik. Menurut Sutanto (2002) istilah sistem pertanian organik menghimpun seluruh imajinasi petani dan konsumen yang secara serius dan bertanggung jawab menghindarkan bahan kimia dan pupuk yang bersifat meracuni lingkungan dengan tujuan untuk memperoleh kondisi lingkungan yang sehat. Dengan demikian, pertanian organik secara tidak langsung telah menjadi gaya hidup masyarakat yang selalu ingin mengkonsumsi produk-produk yang sehat dan bebas dari bahan kimia. Salah satu desa yang telah menerapkan pertanian organik adalah Desa Kebonagung. Di desa ini terdapat satu kelompok tani yang telah menerapkan pertanian organik sejak tahun 2008 dan telah bersertifikat.

Dengan demikian, tujuan penelitan ini adalah: 1) menganalisis hubungan karakteristik petani dengan respon petani pada pertanian organik, 2) menganalisis sejauhmana respon petani pada pertanian organik dapat mempengaruhi kondisi ekonomi petani, 3) menganalisis sejauhmana peluang petani konvesional menerapkan pertanian organik.

\section{Metode Penelitian}

Variebel independen yang digunkan dalam penelitian ini yaitu karakteristik petani yang terdiri dari: tingkat pendidikan formal, tingkat pengalaman bertani, tingkat keberanian mengambil resiko, tingkat jejaring yang dimiliki petani, dan tingkat kepemilikan alat produksi, sedangkan variabel dependent yang digunakan yaitu respon petani pada pertanian organik dan tingkat pendapatan. Jumlah populasi petani di Kelompok Tani Madya (populasi sampling) sebanyak 119 orang. Sampling penelitian ini terdiri dari dua sub populasi (strata), yaitu 46 orang petani organik dan 73 orang petani konvensional. Penelitian ini menggunakan analisis deskriptif kualitatif dan kuantitatif.

\section{Hasil dan Pembahsan}

\section{Profil Kelompok Tani Madya}

Kelompok tani Madya merupakan salah satu organisasi petani yang terdapat di Desa Kebonagung. Kelompok ini bergerak di bidang budidaya tanaman padi dan telah diresmikan oleh Kepala Desa Kebonagung pada 6 Agustus 1981. Ketua kelompok tani Madya pertama adalah seorang kepala dukuh yang bernama Pramogo Suharjo dengan jumlah anggota awal sebanyak 63 orang. Saat ini, kelompok tani Madya diketuai Ngatidjo yang dipilih berdasarkan hasil musyawarah dan kelompok tani ini memiliki anggota sebanyak 119 dengan komposisi 46 orang petani organik dan 73 orang petani konvensional.

Kelompok tani Madya telah sejak tahun 2008 mencoba untuk menerapkan pertanian organik. Kelompok tersebut juga telah mendapatkan sertifikat sebanyak dua kali yaitu pada tahun 2010 dan 2013 sebagai penghargaan yang diberikan oleh Lembaga Sertifikasi Persada. Pada tahun 2010, kelompok tani Madya mendapatkan sertifikat organik dengan No. Register 001-2501-10 karena telah melaksanakan sistem manajemen organik sesuai dengan SNI 01-6792-2002 untuk budidaya tanaman padi. Sertifikat tersebut berlaku dalam waktu tiga tahun dari tanggal 24 Januari 2010 sampai dengan tanggal 24 Januari 2013. Selanjutnya pada tahun 2013, kelompok tani Madya kembali mendapatkan sertifikat organik denga No. 012/P/1012/2012 dari Lembaga Sertifikasi Pangan Organik LSPO-007IDN dan Lembaga Sertifikasi Persada. Sertifikat kedua diberikan kepada kelompok tani Madya 
Tabel 1 Distribusi Penyuluh berdasarkan Karakteristik Individu

\begin{tabular}{|c|c|c|c|c|}
\hline \multirow{2}{*}{ Kara } & \multicolumn{2}{|c|}{ Petani Organik } & \multicolumn{2}{|c|}{ Petani Konvensional } \\
\hline & Jumlah & $(\%)$ & Jumlah & $(\%)$ \\
\hline \multicolumn{5}{|c|}{ Tingkat Pendidikan } \\
\hline Rendah & 17 & 56,67 & 14 & 46,67 \\
\hline Tinggi & 13 & 43,33 & 16 & 53,33 \\
\hline Total & 30 & 100,00 & 30 & 100,00 \\
\hline \multicolumn{5}{|c|}{ Tingkat Pengalaman Bertani } \\
\hline Rendah & 15 & 50,00 & 14 & 46,67 \\
\hline Tinggi & 15 & 50,00 & 16 & 53,33 \\
\hline Total & 30 & 100,00 & 30 & 100,00 \\
\hline \multicolumn{5}{|c|}{$\begin{array}{l}\text { Tingkat Keberanian Mengambil } \\
\text { Resiko }\end{array}$} \\
\hline Rendah & 0 & 0,00 & 19 & 63,33 \\
\hline Tinggi & 30 & 100,00 & 11 & 36,67 \\
\hline Total & 30 & 100,00 & 30 & 100,00 \\
\hline \multicolumn{5}{|c|}{ Tingkat Jejaring } \\
\hline Rendah & 30 & 96,67 & 30 & 100,00 \\
\hline Tinggi & 0 & 3,33 & 0 & 0,00 \\
\hline Total & 30 & 100,00 & 30 & 100,00 \\
\hline \multicolumn{5}{|c|}{$\begin{array}{l}\text { Tingkat kepemilikan alat } \\
\text { produksi }\end{array}$} \\
\hline Rendah & 25 & 83,33 & 21 & 70,00 \\
\hline Tinggi & 5 & 16,67 & 9 & 30,00 \\
\hline Total & 30 & 100,00 & 30 & 100,00 \\
\hline
\end{tabular}

karena telah menerapkan sistem produksi pangan organik sesuai SNI 6729-2010-Organic Food d Production System dan CAC/GL 32/1999 Codex Alimentarius Commission Guidelines for the production, processing, labelling and marketing of organically produced foods. Ruang lingkup sertifikasi adalah padi organik dengan luas lahan 5.7 hektar. Selain penghargaan berbentuk sertifikat yang telah diberikan oleh pemerintah, kelompok tani Madya juga telah mendapatkan beberapa bantuan dari pemerintah Kabupaten Bantul berupa rumah kompos sebagai tempat pembuatan kompos, biogas, traktor, dan kompos.

\section{Karakteristik Responden}

Responden pada penelitian ini berjumlah 60 orang dengan proporsi 30 orang petani organik dan 30 orang petani konvensional. Distribusi petani berdasarkan karakteristik petani disajikan dalam
Tabel 1. Tingkat pendidikan formal merupakan jenjang terakhir sekolah formal yang pernah diikuti oleh responden. Tingkat pendidikan formal petani jika dikalkulasikan cenderung rendah. Sebagian besar petani mengaku bahwa mereka hanya sekolah hingga tamat SD dan sangat sedikit yang meneruskannya ke jenjang yang lebih tinggi. Hal tersebut karena keterbatasan dana sehingga banyak petani yang memilih untuk tidak bersekolah lagi dan meneruskan pekerjaan orang tuanya sebagai petani. Tingkat pengalaman bertani merupakan lamanya responden dalam melakukan usahatani. Tingkat pengalaman bertani jika dikalkulasikan cenderung tinggi. Hal ini menunjukkan bahwa mayoritas anggota kelompok tani Madya memiliki tingkat pengalaman bertani yang tergolong tinggi, yaitu lebih dari 36 tahun. Berdasarkan hasil wawancara yang dilakukan, banyak petani yang mengaku sudah bertani sejak kecil dengan cara membantu kedua orang tua. Namun, terdapat pula petani yang 
Tabel 2 Jumlah dan Persentase Responden menurut Tingkat Pengetahuan, Penerapan, Respon Petani pada Pertanian Organik, Kelompok Tani Madya, 2013

\begin{tabular}{|c|c|c|c|c|}
\hline \multirow{2}{*}{ Kara } & \multicolumn{2}{|c|}{ Petani Organik } & \multicolumn{2}{|c|}{ Petani Konvensional } \\
\hline & Jumlah & $(\%)$ & Jumlah & $(\%)$ \\
\hline \multicolumn{5}{|c|}{ Tingkat Pendidikan } \\
\hline Rendah & 17 & 56,67 & 14 & 46,67 \\
\hline Tinggi & 13 & 43,33 & 16 & 53,33 \\
\hline Total & 30 & 100,00 & 30 & 100,00 \\
\hline \multicolumn{5}{|c|}{ Tingkat Pengalaman Bertani } \\
\hline Rendah & 15 & 50,00 & 14 & 46,67 \\
\hline Tinggi & 15 & 50,00 & 16 & 53,33 \\
\hline Total & 30 & 100,00 & 30 & 100,00 \\
\hline \multicolumn{5}{|c|}{$\begin{array}{l}\text { Tingkat Keberanian Mengambil } \\
\text { Resiko }\end{array}$} \\
\hline Rendah & 0 & 0,00 & 19 & 63,33 \\
\hline Tinggi & 30 & 100,00 & 11 & 36,67 \\
\hline Total & 30 & 100,00 & 30 & 100,00 \\
\hline \multicolumn{5}{|c|}{ Tingkat Jejaring } \\
\hline Rendah & 30 & 96,67 & 30 & 100,00 \\
\hline Tinggi & 0 & 3,33 & 0 & 0,00 \\
\hline Total & 30 & 100,00 & 30 & 100,00 \\
\hline \multicolumn{5}{|c|}{$\begin{array}{l}\text { Tingkat kepemilikan alat } \\
\text { produksi }\end{array}$} \\
\hline Rendah & 25 & 83,33 & 21 & 70,00 \\
\hline Tinggi & 5 & 16,67 & 9 & 30,00 \\
\hline Total & 30 & 100,00 & 30 & 100,00 \\
\hline
\end{tabular}

lama bertaninya kurang dari sepuluh tahun karena didorong oleh kebutuhan keluarga.

Tingkat keberanian mengambil resiko merupakan keberanian petani dalam mengambil keputusan meskipun memiliki resiko. Keberanian mengambil resiko petani organik cenderung tinggi dibandingkan petani konvensional. Hal ini karena terdapat petani konvensional yang tidak lagi menerapkan pertanian organik murni karena pada saat menerapkannya hasil panen yang didapat berkurang.

Tingkat jejaring merupakan interaksi petani dengan petani lain maupun dengan penyuluh pertanian untuk mendapatkan informasi mengenai pertanian organik. Tingkat jejaring pada petani organik maupun petani konvensional tingkat jejaring berada pada kategori rendah. Rendahnya tingkat jejaring yang dimiliki disebabkan oleh responden petani organik dan konvensional mendapatkan informasi mengenai pertanian organik hanya dari rekan satu kelompok tani dan penyuluh pertanian tingkat Kabupaten Bantul. Pada Kelompok Tani Madya setiap petani telah menjalin hubungan yang cukup baik sehingga dapat terjalin proses pertukaran ilmu dan pengetahuan mengenai pertanian organik. Penyuluhan yang dilakukan oleh Dinas Kabupaten Bantul dan Yogyakarta ternyata memiliki peranan yang besar dalam memberikan informasi. Sehingga meskipun tidak ada petani yang mendapatkan informasi dari sesama petani berbeda desa maupun dari penyuluh di luar Yogyakarta, informasi yang didapat dari dalam kelompok itu pun dianggap sudah cukup, bahkan telah membuat lahan pertanian di Desa Kebonagung ada yang bersertifikat organik. Tingkat kepemilikan alat produksi merupakan jenis alat produksi yang dimiliki oleh petani yang dilihat dari indikator kepemilikan sawah dan hewan ternak. Tingkat kepemilikan alat produksijika dikalkulasikan 
Tabel 3 Hubungan antara Tingkat Pendidikan Formal dengan Respon Petani pada Pertanian Organik

\begin{tabular}{|c|c|c|c|c|c|c|c|c|c|c|c|c|}
\hline \multicolumn{13}{|c|}{ Tingkat Pendidikan Petani } \\
\hline \multirow{3}{*}{$\begin{array}{c}\text { Respon } \\
\text { Petani }\end{array}$} & \multicolumn{6}{|c|}{ Petani Organik } & \multicolumn{6}{|c|}{ Petani Konvensional } \\
\hline & \multicolumn{2}{|c|}{ Rendah } & \multicolumn{2}{|c|}{ Tinggi } & \multicolumn{2}{|c|}{ Jumlah } & \multicolumn{2}{|c|}{ Rendah } & \multicolumn{2}{|c|}{ Tinggi } & \multicolumn{2}{|c|}{ Jumlah } \\
\hline & f & $\%$ & f & $\%$ & f & $\%$ & f & $\%$ & f & $\%$ & f & $\%$ \\
\hline Rendah & 0 & 0,00 & 0 & 0,00 & 0 & 0,00 & 8 & 57,14 & 6 & 37,50 & 14 & 46,67 \\
\hline Tinggi & 17 & 100,00 & 13 & 100,00 & 30 & 100,00 & 6 & 42,86 & 10 & 62,50 & 16 & 53,33 \\
\hline Jumlah & 17 & 100,00 & 13 & 100,00 & 30 & 100,00 & 14 & 100,00 & 16 & 100,00 & 30 & 100,00 \\
\hline
\end{tabular}

cenderung rendah. Hal itu karena hanya sedikit petani yang memiliki kedua alat produksi seperti lahan pertanian dan hewan ternak. Mayoritas petani di Kelompok Tani Madya hanya memiliki lahan pertanian saja. Hal tersebut sudah dianggap cukup karena pupuk dapat diperoleh dengan mudah, yaitu petani dapat membeli langsung dari kios alat pertanian, menggunakan bekas tanaman, atau meminta kotoran ternak milik rekanan. Selain itu, hewan ternak juga sudah jarang sekali digunakan untuk membajak. Petani dapat membajak tanah menggunakan traktor milik kelompok.

\section{Hubungan Antara Karakteristik Petani dengan Respon Petani Pada Pertanian Organik}

\section{Respon Petani Pada Pertanian Organik}

Respon petani adalah perubahan tingkah laku yang terjadi pada petani sebagai akibat adanya pertanian organik. Dalam penelitian ini, respon petani dilihat melalui dua indikator yaitu tingkat pemahaman dan tingkat penerapan pertanian organik. Tingkat pemahaman, penerapan, dan respon petani pada pertanian organik dapat dilihat pada Tabel 2.

Berdasarkan Tabel 2, dapat diketahui adanya perbedaan penerapan pada petani organik dan petani konvensional. Responden pada penelitian ini merupakan petani yang berada pada satu kelompok. Namun, meskipun tingkat pemahaman petani tinggi, tingkat penerapan pada petani konvensional masih rendah. Hal ini karena pada dasarnya kelompok tani Madya adalah kelompok yang menerapkan sistem usaha tani terpadu atau yang lebih di kenal dengan petani kelompok Madya dengan pengelolaan tanaman terpadu (PTT).

Menurut Sutanto (2002) sistem usaha tani terpadu merupakan salah satu peluang pertanian organik yang dapat diterapkan dengan memperhatikan kondisi lokasi yang spesifik. Sistem usaha tani terpadu ini menggunakan masukan teknologi yang rendah dengan sistem pertanian organik dan sumberdaya lokal didaur ulang secara efektif. Hal ini sesuai dengan keadaan di lapangan yang menunjukkan bahwa pada petani konvensional sebagian besar dari mereka menggunakan pupuk organik dan pupuk kimia. Menurut penuturan Mrg (45 tahun), petani konvensional juga tidak selalu menggunakan pestisida kimia sintetik. Pestisida kimia sintetik tersebut digunakan sesuai kebutuhan saja, yaitu apabila hama di sawah sudah melebihi ambang batas. Namun karena petani konvensional masih menggunakan pupuk maupun pestisida kimia, hal tersebutlah yang menyebabkan tingkat penerapan pada pertanian organik rendah. Karena seharusnya

Tabel 4 Hubungan antara Tingkat Pengalaman Bertani dengan Respon Petani pada Pertanian Organik

\begin{tabular}{|c|c|c|c|c|c|c|c|c|c|c|c|c|}
\hline \multirow{4}{*}{$\begin{array}{l}\text { Respon } \\
\text { Petani }\end{array}$} & \multicolumn{12}{|c|}{ Tingkat Pengalaman Bertani } \\
\hline & \multicolumn{6}{|c|}{ Petani Organik } & \multicolumn{6}{|c|}{ Petani Konvensional } \\
\hline & \multicolumn{2}{|c|}{ Rendah } & \multicolumn{2}{|c|}{ Tinggi } & \multicolumn{2}{|c|}{ Jumlah } & \multicolumn{2}{|c|}{ Rendah } & \multicolumn{2}{|c|}{ Tinggi } & \multicolumn{2}{|c|}{ Jumlah } \\
\hline & f & $\%$ & $\mathbf{f}$ & $\%$ & $\mathbf{f}$ & $\%$ & f & $\%$ & f & $\%$ & f & $\%$ \\
\hline Rendah & 0 & 0,00 & 0 & 0,00 & 15 & 50,00 & 6 & 42,86 & 8 & 50,00 & 14 & 46,67 \\
\hline Tinggi & 15 & 100,00 & 15 & 100,00 & 15 & 50,00 & 8 & 57,14 & 8 & 50,00 & 16 & 53,33 \\
\hline Jumlah & 15 & 100,00 & 15 & 100,00 & 30 & 100,00 & 14 & 100,00 & 16 & 100,00 & 30 & 100,00 \\
\hline
\end{tabular}


Tabel 5 Hubungan antara Tingkat Keberanian Mengambil Resiko dengan Respon Petani pada Pertanian Organik

\begin{tabular}{|c|c|c|c|c|c|c|c|c|c|c|c|c|}
\hline \multirow{4}{*}{$\begin{array}{l}\text { Respon } \\
\text { Petani }\end{array}$} & \multicolumn{12}{|c|}{ Tingkat Keberanian Mengambil Resiko } \\
\hline & \multicolumn{6}{|c|}{ Petani Organik } & \multicolumn{6}{|c|}{ Petani Konvensional } \\
\hline & \multicolumn{2}{|c|}{ Rendah } & \multicolumn{2}{|c|}{ Tinggi } & \multicolumn{2}{|c|}{ Jumlah } & \multicolumn{2}{|c|}{ Rendah } & \multicolumn{2}{|c|}{ Tinggi } & \multicolumn{2}{|c|}{ Jumlah } \\
\hline & f & $\%$ & f & $\%$ & f & $\%$ & f & $\%$ & f & $\%$ & f & $\%$ \\
\hline Rendah & 0 & 0,00 & 0 & 0,00 & 0 & 0,00 & 10 & 52,63 & 4 & 36,36 & 14 & 46,67 \\
\hline Tinggi & 0 & 0,00 & 30 & 100,00 & 30 & 100,00 & 9 & 47,37 & 7 & 63,64 & 16 & 53,33 \\
\hline Jumlah & 0 & 0,00 & 30 & 100,00 & 30 & 100,00 & 19 & 100,00 & 11 & 100,00 & 30 & 100,00 \\
\hline
\end{tabular}

pertanian organik murni itu menggunakan pupuk organik, pupuk hayati, dan pestisida hayati dan menghindarkan penggunaan pupuk kimia dan pestisida/bahan kimia pertanian (Sutanto, 2002).

Fakta lain yang diperoleh di lapangan adalah sistem pengairan irigasi pada kelompok tani Madya masih tercampur antara lahan organik maupun lahan konvensional. Kelompok tani Madya menggunakan perairan yang berasal dari Sungai Opak (Bendungan Canden Kiri). Sehingga pada lahan organik pun masih terdapat campuran bahan kimia yang berasal dari air tersebut.

\section{Hubungan Karakteristik Petani dengan Respon Petani Pada Pertanian Organik}

Hubungan antara karakteristik individu dan respon petani pada pertanian organik cenderung tidak nyata karena skor respon petani pada pertanian organik cenderung sama yaitu tinggi (Tabel 2). Respon petani organik pada pertanian organik sama, yaitu tinggi. Begitu juga dengan respon petani konvensional pada pertanian organik sebagian besar petani cenderung tinggi. Beberapa petani baik pada pertanian organik maupun pertanian konvensional memiliki skor karakteristik yang rendah tetapi respon pada pertanian organiknya tinggi. Hal tersebut menunjukkan bahwa hasil penelitian tidak menunjukkan adanya hubungan antara karakteristik petani dengan respon petani pada pertanian organik. Hasil tabulasi silang antara karakteristik petani dengan respon para petani pada pertanian organik disajikan pada Tabel 3 hingga Tabel 7.

Berdasarkan Tabel 3, dapat dianalisa bahwa pada petani organik, tidak terdapat hubungan antara tingkat pendidikan formal dengan respon petani, sedangkan pada petani konvensional terdapat hubungan antara tingkat pendidikan formal dengan respon petani pada pertanian organik. Sesungguhnya pendidikan formal memiliki peranan bagi petani. Semakin tinggi pendidikan petani, maka seharusnya semakin tinggi pula respon petani pada pertanian organik. Namun, pada seluruh responden terlihat adanya kebebasan dalam memahami dan menerapkan pertanian organik sehingga dapat menghasilkan respon yang tinggi. Artinya, petani yang memiliki pendidikan rendah juga bebas untuk memahami informasi yang dapat memberikan penghidupan lebih baik. Karena ilmu dan pengetahuan tidak selalu berasal dari pendidikan formal, tetapi juga didapat dari pendidikan non formal maupun dari hasil pengalaman selama hidup. Selain itu, diduga adanya motivasi lain yang mendorong petani untuk menerapkan pertanian organik.

Tabel 6 Hubungan antara Jejaring dengan Respon Petani pada Pertanian Organik

\begin{tabular}{|c|c|c|c|c|c|c|c|c|c|c|c|c|}
\hline \multirow{4}{*}{$\begin{array}{l}\text { Respon } \\
\text { Petani }\end{array}$} & \multicolumn{12}{|c|}{ Tingkat Keberanian Mengambil Resiko } \\
\hline & \multicolumn{6}{|c|}{ Petani Organik } & \multicolumn{6}{|c|}{ Petani Konvensional } \\
\hline & \multicolumn{2}{|c|}{ Rendah } & \multicolumn{2}{|c|}{ Tinggi } & \multicolumn{2}{|c|}{ Jumlah } & \multicolumn{2}{|c|}{ Rendah } & \multicolumn{2}{|c|}{ Tinggi } & \multicolumn{2}{|c|}{ Jumlah } \\
\hline & $\mathbf{f}$ & $\%$ & $\mathbf{f}$ & $\%$ & f & $\%$ & $\mathbf{f}$ & $\%$ & $\mathbf{f}$ & $\%$ & $\mathbf{f}$ & $\%$ \\
\hline Rendah & 0 & 0,00 & 0 & 0,00 & 0 & 0,00 & 14 & 46,67 & 0 & 0,00 & 14 & 46,67 \\
\hline Tinggi & 30 & 100,00 & 0 & 0,00 & 30 & 100,00 & 16 & 53,33 & 0 & 0,00 & 16 & 53,33 \\
\hline Jumlah & 30 & 100,00 & 0 & 0,00 & 30 & 100,00 & 30 & 100,00 & 0 & 0,00 & 30 & 100,00 \\
\hline
\end{tabular}


Tabel 7 Hubungan antara Kepemilikan Alat Produksi dengan Respon Petani pada Pertanian Organik

\begin{tabular}{|c|c|c|c|c|c|c|c|c|c|c|c|c|}
\hline \multirow{4}{*}{$\begin{array}{l}\text { Respon } \\
\text { Petani }\end{array}$} & \multicolumn{12}{|c|}{ Tingkat Kepemilikan Alat Produksi } \\
\hline & \multicolumn{6}{|c|}{ Petani Organik } & \multicolumn{6}{|c|}{ Petani Konvensional } \\
\hline & \multicolumn{2}{|c|}{ Rendah } & \multicolumn{2}{|c|}{ Tinggi } & \multicolumn{2}{|c|}{ Jumlah } & \multicolumn{2}{|r|}{ Rendah } & \multicolumn{3}{|c|}{ Tinggi } & \multirow{2}{*}{$\begin{array}{c}\text { Jumlah } \\
\%\end{array}$} \\
\hline & f & $\%$ & f & $\%$ & f & $\%$ & f & $\%$ & f & $\%$ & f & \\
\hline Rendah & 0 & 0,00 & 0 & 0,00 & 0 & 0,00 & 10 & 47,62 & 4 & 44,44 & 14 & 46,67 \\
\hline Tinggi & 25 & 100,00 & 5 & 100,00 & 30 & 100,00 & 11 & 52,38 & 5 & 55,56 & 16 & 53,33 \\
\hline Jumlah & 25 & 100,00 & 5 & 100,00 & 30 & 100,00 & 21 & 100,00 & 9 & 100,00 & 30 & 100,00 \\
\hline
\end{tabular}

Berdasarkan Tabel 4 dapat dianalisa bahwa tidak terdapat hubungan antara tingkat pengalaman bertani dengan respon petani pada pertanian organik. Petani yang memiliki tingkat pengalaman bertaninya tinggi cenderung memiliki respon yang tinggi pada pertanian organik. Fakta di lapangan yang ditemukan oleh peneliti adalah mayoritas anggota Kelompok Tani Madya adalah generasi tua. Tingginya pengalaman diduga dapat menyebabkan petani telah memahami dengan pasti kondisi pertaniannya. Dengan demikian, respon yang tinggi pada pertanian organik merupakan bentuk dari petani yang mencoba untuk memperbaiki sistem bertaninya.

Berdasarkan Tabel 5 dapat dianalisa bahwa pada petani organik tidak terdapat hubungan karena tidak terdapat satu pun petani yang memiliki tingkat keberanian resiko dan respon pada pertanian organik yang rendah. Mereka semua memiliki keberanian resiko dan respon pada pertanian organik yang tinggi. Hal ini dapat menjadi salah satu alasan bahwa sampai penelitian ini dilaksanakan lahan pertanian kelompok Tani Madya ada yang telah mendapatkan sertifikat dari Dinas Pertanian Bantul. Petani organik termasuk dalam petani yang memiliki keberanian mengambil resiko tinggi. Meskipun pada awal diterapkan pertanian organik pada lahan mereka hasil panen sedikit menurun hal tersebut tidak menjadi alasan petani untuk tidak berorganik. Sedangkan, pada petani konvensional dari tabel tabulasi silang dapat dilihat bahwa semakin rendah keberanian mengambil resiko, maka semakin rendah pula respon petani pada pertanian organik. Hal ini terbukti dari hanya sedikit petani yang mau menggunakan pupuk organik, apalagi membuat pupuk kandang sendiri karena terbentur oleh masalah waktu.

Tingkat jejaring tidak memiliki hubungan dengan respon petani organik maupun konvensional pada pertanian organik. Hal tersebut disebabkan oleh penyuluh yang memberikan penyuluhan mengenai pertanian organik pada kelompok tersebut hanya berasal dari wilayah Yogyakarta, baik tingkat kabupaten maupun provinsi. Meskipun demikian ternyata respon yang diberikan oleh petani hampir seluruhnya merupakan respon positif. Artinya, mereka mau memahami dan menerapkan pertanian organik. Selain dari penyuluh, informasi mengenai pertanian organik juga didapatkan dari rekan sesama petani kelompok tani Madya.

Berdasarkan Tabel 7 dapat dianalisa bahwa tidak terdapat hubungan antara tingkat kepemilikan alat produksi dengan respon petani organik maupun konvensional pada pertanian organik. Tingginya kepemilikan alat produksi tidak selalu dapat mendorong petani untuk memiliki respon yang tinggi pada pertanian organik. Fakta di lapangan menunjukkan bahwa hewan ternak di petani belum tentu digunakan sebagai penunjang dalam menerapkan pertanian. Terdapat beberapa responden petani konvensional yang mengaku hewan ternak yang dimiliki merupakan warisan dan tidak semuanya memanfaatkan kotorannya untuk dijadikan pupuk (kompos). Terdapat pula petani yang justru memberikan hasil kotoran tersebut untuk dijadikan kompos oleh petani lain.

\section{Analisis Tingkat Pendapatan dan Akses Pasar}

Tingkat pendapatan merupakan ukuran taraf hidup yang dilihat dari jumlah penghasilan petani dari mata pencahariannya sebagai petani dilihat dari hasil panen terakhir dikurangi dengan biaya produksi. Berdasarkan hasil perhitungan, diketahui bahwa rata-rata pendapatan bersih petani organik lebih tinggi dibandingkan dengan pendapatan petani konvensional. Pendapatan petani organik rata-rata $\mathrm{Rp}$ 2.984.367 dengan hasil panen ratarata yaitu $935,9 \mathrm{~kg}$. Sedangkan pendapatan petani 
Tabel 8 Distribusi Petani berdasarkan Tingkat Pendapatan dan Akses Pasar

\begin{tabular}{lrccc}
\hline \multicolumn{2}{c}{ Kategori Jumlah } & $\begin{array}{c}\text { Petani Organik } \\
\text { Persentase } \\
\mathbf{( \% )}\end{array}$ & $\begin{array}{c}\text { Petani Konvensional } \\
\text { Jumlah }\end{array}$ & $\begin{array}{c}\text { Persentase } \\
\mathbf{( \% )}\end{array}$ \\
\hline Tingkat Pendapatan & $\mathbf{f}$ & & & \\
Rendah & 11 & 36,7 & 22 & 73,33 \\
Tinggi & 19 & 63,3 & 8 & 26,67 \\
\hline Total & 30 & 100,00 & 30 & 100,00 \\
\hline Akses Pasar & & & & 0,00 \\
Rendah & 0 & 0,00 & 0 & 100,00 \\
Tinggi & 30 & 100,00 & 30 & 100,00 \\
\hline Total & 30 & 100,00 & 30 & \\
\hline
\end{tabular}

konvensional rata-rata yaitu $\mathrm{Rp} 2.444 .867$ dengan hasil panen rata-rata $602,67 \mathrm{~kg}$. Tinggi $/$ rendahnya pendapatan petani tidak hanya bergantung pada jumlah panen, tetapi juga pada harga yang diberikan pasar. Pada saat penelitian ini dilaksanakan, harga jual gabah organikke penggilingan sebesar $\mathrm{Rp}$ 3.600 sampai Rp 3.800, sedangkan harga jual gabah konvensional ke penggilingan sebesar Rp 3.200 sampai Rp 3.400 dan ke penangkar benih sebesar Rp 3.900.

Akses pasar merupakan potensi atau peluang petani dalam memasarkan atau menjual produk pertaniannya kepada konsumen melalui berbagai macam saluran distribusi berdasarkan permintaan konsumen. Tabel 8 menunjukkan bahwa akses pasar petani berada pada kategori tinggi. Petani telah memiliki tempat langganan untuk menjual hasil panen dan juga telah mengetahui adanya peluang untuk menjual ke tempat lain. Petani organik mengaku bahwa hasil panen juga bisa secara bebas dijual kepada konsumen. Untuk harga jual, biasanya sebelum panen dilakukan kumpul kelompok untuk menentukan harga jual yang sesuai dengan kondisi pasar sebagai gambaran apakah harga beli yang ditawarkan oleh penggiling beras sudah sesuai dengan harga pasar.

\section{Hubungan Respon Petani pada Pertanian Organik dengan Tingkat Pendapatan}

Petani memiliki pendapatan yang cenderung berbeda, yaitu petani organik memiliki pendapatan tinggi dan petani konvensional memiliki pendapatan rendah (Tabel 8). Hasil penelitian ini menunjukkan bahwa semakin tingginya respon petani pada pertanian organik ternyata tidak menunjukkan tingkat pendapatan yang semakin tinggi. Hasil tabulasi silang antara respon petani pada pertanian organik dengan tingkat pendapatan disajikan pada Tabel 9.

Tidak terdapat hubungan antara respon petani pada pertanian organik dengan tingkat pendapatan. Meskipun demikian, petani organik yang memiliki pendapatan rendah tidak menyebabkan petani tersebut untuk kembali lagi menjadi petani konvensional. Hal ini karena penerapan pertanian organik yang dilakukan atas kesadaran pribadi petani masing-masing dengan tidak terlalu terfokus pada pendapatan yang diterima dari hasil panen. Karena tidak semua petani menjual hasil panennya, melainkan hanya sebagai konsumsi keluarga sendiri.

\section{Keunggulan Padi Organik}

Pada dasarnya petani organik di kelompok tani Madya telah merasakan manfaat setelah mengubah pertanian mereka menjadi pertanian organik. Seluruh petani organik yang menjadi responden penelitian ini mengaku bahwa hasil beras dari pertanian organik lebih enak daripada pertanian konvensional dan memiliki harga jual yang lebih tinggi. Petani dapat menggunakan beras hasil pertaniannya sendiri untuk makan, berbeda dengan petani konvensional yang perlu membeli beras untuk kebutuhan makan sehari-hari. Sehingga petani dapat meminimalkan pengeluaran rumah tangga untuk membeli beras karena dapat mengkonsumsi beras hasil pertanian sendiri dan dapat menggunakannya 
Tabel 9 Hubungan antara Respon Petani pada Pertanian Organik dengan Tingkat Pendapatan

\begin{tabular}{|c|c|c|c|c|c|c|c|c|c|c|c|c|}
\hline \multirow{4}{*}{ Pendapatan } & \multicolumn{12}{|c|}{ Respon Petani pada Pertanian Organik } \\
\hline & \multicolumn{6}{|c|}{ Petani Organik } & \multicolumn{6}{|c|}{ Petani Konvensional } \\
\hline & \multicolumn{2}{|c|}{ Rendah } & \multicolumn{2}{|c|}{ Tinggi } & \multicolumn{2}{|c|}{ Jumlah } & \multicolumn{2}{|c|}{ Rendah } & \multicolumn{2}{|c|}{ Tinggi } & \multicolumn{2}{|c|}{ Jumlah } \\
\hline & f & $\%$ & f & $\%$ & f & $\%$ & f & $\%$ & f & $\%$ & f & $\%$ \\
\hline Rendah & 0 & 0,00 & 11 & 36,67 & 11 & 36,67 & 11 & 78,57 & 11 & 68,75 & 22 & 73,33 \\
\hline Tinggi & 0 & 0,00 & 19 & 63,33 & 19 & 63,33 & 3 & 21,43 & 5 & 31,25 & 8 & 26,67 \\
\hline Jumlah & 0 & 0,00 & 30 & 100,00 & 30 & 100,00 & 14 & 100,00 & 16 & 100,00 & 30 & 100,00 \\
\hline
\end{tabular}

untuk keperluan lainnya. Pertanian organik juga menggunakan input eksternal yang rendah dengan mengoptimalkan penggunaan asupan alami yang ada di sekitar melalui proses daur ulang bahan-bahan alami. Petani dapat menghemat penggunaan benih dan memanfaatkan sisa tanaman dengan mendaur ulang daun-daun telah mati. Selain itu petani juga dapat memanfaatkan kotoran ternak sehingga lingkungan sekitar tidak mengalami kesulitan untuk membuang kotoran ternak tersebut.

Praktik pertanian organik terbukti menguntungkan secara ekonomi. Dari keuntungan ekonomi yang diperoleh, keuntungan tersebut dapat dimanfaatkan untuk memenuhi kebutuhannya. Pertanian organik berupaya untuk menciptakan pasar yang berpihak kepada petani organik. Selain harga jual gabah yang lebih tinggi daripada gabah hasil pertanian konvensional, petani juga memiliki kesempatan untuk ikut menentukan harga jual atas produk yang telah mereka hasilkan.

\section{Peluang Penerapan Pertanian Organik Pada Petani Konvensional}

Penelitian Sutanto (2002) mendefinisikan bahwa pertanian organik bertujuan untuk mengelola pertanian dan ekosistem sekaligus bersama-sama. Petani harus mampu mengelola pertaniannya dengan menggunakan segala sumber daya yang berasal dari lingkungan tinggalnya. Hal tersebut perlu diterapkan untuk meminimalkan ketergantungan petani pada pupuk dan pestisida kimia yang sebelumnya telah mereka gunakan. Penerapan pertanian organik hanya akan berhasil baik di wilayah atau tempat yang secara alami cukup bahan organik dan ketersediaan pupuk kimia terbatas atau bahkan tidak ada sama sekali (Susanto, 2002).

Berdasarkan hasil penggalian informasi di lapangan, ternyata ditemui banyak permasalahan yang menjadi penghalang sulitnya pertanian organik berkembang dengan cepat. Permasalahan itu diantaranya adalah petani konvensional masih takut untuk benar-benar menerapkan pertanian organik yang bebas dari penggunaan pestisida atau pupuk kimia sintetik, petani membutuhkan segala sesuatu untuk usahataninya yang cepat sehingga petani lebih suka dan terbiasa untuk membeli daripada memanfaatkan lingkungan sekitar, dan terdapat petani tidak puas dengan hasil panen yang sedikit pada saat pertama kali menerapkan pertanian organik.

Permasalahan yang terdapat di kelompok tani Madya tersebut menyebabkan petani kelompok tani Madya digolongkan sebagai petani yang menerapkan sistem usaha tani terpadu dengan menggunakan masukan teknologi rendah dengan sistem pertanian organik dan sumber daya lokal didaur-ulang secara efektif. Hal ini juga menunjukkan bahwa terdapat peluang untuk dikembangkannya pertanian organik murni pada kelompok tani Madya. Keadaan ini didukung dengan setiap anggota memiliki kekerabatan yang dekat dan kepercayaan yang tinggi dengan ketua kelompok dan anggota kelompok lainnya. Sehingga hal ini diduga dapat menjadi nilai positif bahwa pertanian organik dapat dikembangkan melalui pertemuan dan sosialisasi yang intensif dari kelompok selain penyuluhan yang dilakukan oleh pemerintah. Selain itu, pendidikan formal dan pengalaman bertani yang tinggi pada petani konvensional diprediksikan membantu petani untuk lebih memahami dan mau mengubah sistem pertanian yang selaras dengan alam.

\section{Kesimpulan}

Kesimpulan penelitian ini yaitu: 1) tidak terdapat hubungan antara karakteristik petani organik dengan respon petani pada pertanian organik 
dan terdapat hubungan antara pendidikan formal dan keberanian mengambil resiko petani konvensional dengan respon petani pada pertanian organic, 2) tidak terdapat hubungan antara respon petani pada pertanian organik dengan pendapatan petani. Hal ini terjadi bahwa karena tinggi rendahnya pendapatan petani tergantung pada nilai jual hasil pertanian yang dihasilkan, 3) terdapat peluang yang cukup besar pada petani konvensional untuk menerapkan pertanian organik.

\section{Daftar Pustaka}

[Anonim]. 2011. Profil Desa Kebonagung. Yogyakarta(ID): Puswira Yogyakarta. [Internet]. [dapat diunduh dari: http://www.scribd.com].

Ariesusanty R, Nuryati S, Wangsa R. 2012. Statistik pertanian organik Indonesia - 2011. Bogor (ID): Aliansi Organis Indonesia

Badan Pusat Statistik. 2011. Potensi Desa 2011. Yogyakarta (ID).

Badan Pusat Statistik. 2012. Penduduk 15 tahun ke atas yang bekerja menurut lapangan pekerjaan utama 2004 - 2012. [Internet]. [dapat diunduh dari: http://www.bps.go.id].

Putri NI. 2011. Penerapan teknologi pertanian padi organik di Kampung Ciburuy, Desa Ciburuy, Kecamatan Cigombong, Kabupaten Bogor. [skripsi]. Bogor (ID): Institut Pertanian Bogor

Reijntjes C, Haverkort B, Bayer AW. 1999. Pertanian masa depan: pengantar untuk pertanian berkelanjutan dengan input luar rendah. Yogyakarta (ID): Kanisius
Rukka, Buhaerah, Sunaryo. 2006. Hubungan karakteristik petani dengan respon petani terhadap penggunaan pupuk organik pada padi sawah (Oriza sativa L.). [Internet]. [Diunduh pada 10 Maret 2013].

Salikin KA. 2003. Sistem pertanian berkelanjutan. Yogyakarta (ID): Kanisius

Saragih SE. 2008. Pertanian organik solusi hidup harmoni dan berkelanjutan. Depok (ID): Penebar Swadaya

Sarwono SW. 2003. Teori-Teori Psikologi Sosial. Jakarta (ID): Raja Grafindo Persada.

Siahaan L. 2009. Strategi pengembangan padi organik Kelompok Tani Sisandi, Desa Baruara, Kabupaten Toba Samosir, Sumatera Utara. [skripsi]. Bogor (ID): Institut Pertanian Bogor.

Susanti LW, Sugihardjo, Suwarto. 2008. FaktorFaktor yang mempengaruhi pengambilan keputusan petani dalam penerapan pertanian padi organik di Desa Sukorejo Kecamatan Sambirejo Kabupaten Sragen. [Internet]. [Diunduh 1 April 2013].

Sutanto R. 2002. Pertanian organik menuju pertanian alternatif dan berkelanjutan. Yogyakarta (ID): Kanisius

Widiarta A. 2011. Analisis Berlanjutan Praktik Pertanian Organik Di Kalangan Petani. [skripsi]. Bogor (ID): Institut Pertanian Bogor. 